\title{
Iraqi EFL Teachers' Awareness and Use of Micro and Macro-skills
}

\section{Lecturer , Faris Kadhim Te'ima , Ph.D}

\section{University of Wassit}

\section{College of Education}

\begin{abstract}
English Language learning and teaching require the mastery of a set of skills from which the four main skills , namely ; listening, speaking, reading and writing .Each one of these four skills has a set of subskills which are referred to as micro (minor) skills and macro(major) skills . Knowledge of these subskills is necessary for EFL teachers since the process of teaching and testing English isn't carried out without having knowledge of these skills.They are thought as indispensible part of the process of English language teaching through which the teachers can set objectives, analyze the lesson, set tests , assign the required time for each activity, etc. To find out the Iraqi EFL language teachers' awareness and use of micro and macro- skills, an interview and a questionnaire are made to which a sample of Iraqi EFL teachers are exposed. The obtained results show that Iraqi EFL teachers are unaware of the micro and macro skills and almost they don't use them in teaching .
\end{abstract}

Keywords : awareness , micro-skills , and macro-skills

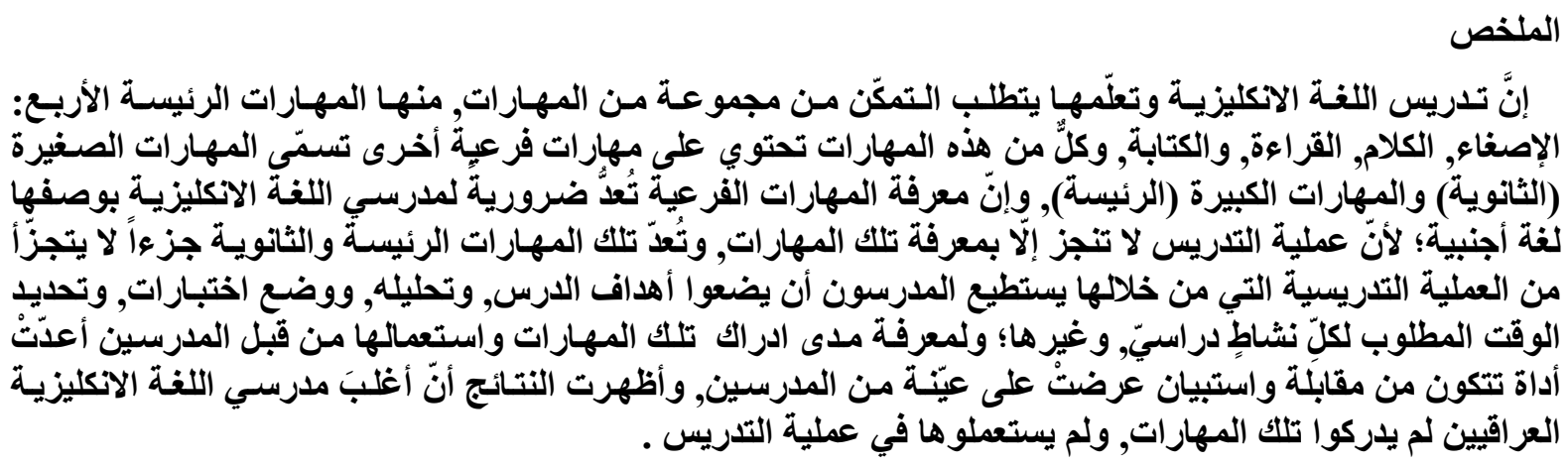

\section{Section One : Introduction}

\section{The Problem of the Study}

English language has four main skills namely: listening, speaking, reading and writing which always take this order of hierarchy. These skills are usually divided according to the type of relations between them which take the a form of pairs as receptive , that is : listening and reading , and productive skills, that is ; speaking and writing. This way of classifying language skills is followed and confirmed by many scholars such as that of Brown $(Y \cdots \vee)$ who states that the four language skills are connected to each other according to the communication direction if it is in or out and the way and method of communication if it is spoken or a written one, in other words it is based on the two reception and production phases . Moreover, these four language skills are also referred to as "macro-skills" which are in contrast with the " micro-skills ",which are things like grammar, vocabulary and pronunciation (Richards ,,$\cdot 1 r$ ).

Having knowledge of micro-skills (minor skills) and macro (major skills) is crucial a great extent for language teachers because they are considered the basis for teaching and learning, and testing. For example , Brown ( $\left.{ }^{\prime} \cdot \vee, p . \wedge \vee\right)$ asserts that the acquisition of micro and macro skills is necessary to assign as a whole and integrated things our learners need in their learning and performance. As you plan for s specific technique, these skills help you to understand the target objectives. These skills also help in doing evaluation for any methods or technique in teaching since it helps as testing criteria .(Ibid) 
In addition to the above-mentioned, Harwood $\left(r_{\cdot}\right) \cdot$, p. $\left.)^{\cdot 0}\right)$ adds that language teaching include different macro skills necessary for communicating; listening, speaking, reading and writing. Good language teachers are those who plan lessons, and sequence their lessons basing on a mixtures of all these macro-skills .

It has been noticed that English language teachers in general including Iraqi ones aren't aware of these micro and macro skills or they are almost ignorant of how to use them in their work during teaching and testing processes. This fact is much asserted by Brown $(Y \cdots$, , p. $Y r)$ who claims that these skills aren't often given attention by teachers as an area of pedagogical intents. Therefore, the present research is an attempt to investigate Iraqi EFL teachers' awareness and use of micro and macro skills .

\section{Aims}

The present study aims at:

1. Presenting a due account regarding meanings of micro and macro skills, importance and the differences between them.

r. Investigating the Iraqi EFL teachers' awareness of micro and macro skills

$r$. Investigating the Iraqi EFL teachers' use of micro and macro skills.

\section{Limits}

The study is limited to:

1. Iraqi EFL teachers who teach English language adopting the prescribed textbook ( English for Iraq ) at intermediate and preparatory schools .

$r$. Directory of Education in the Wassit province.

$r$. The academic year $\left(r \cdot 1 r_{-} r \cdot \mid r\right)$.

\section{Hypothesis}

It is hypothesized that:

1. Iraqi EFL teachers are aware of micro and macro skills in their teaching English language

r. They use the micro and macro-skills in their teaching English lessons .

\section{Procedures:}

The following are procedures followed in the present study :

1. Choosing a sample of Iraqi EFL teachers;

r. Designing tools ( an interview and a questionnaire) to achieve the aims of the study and to verify its hypotheses;

r. Analyzing and discussing the results obtained.

\section{Section Two: Theoretical Background}

\section{Micro and Macro Skills Meanings}

The term micro comes from the Greek word "mikros" meaning "small, little " ; on the other hand the term "macro" which is also of the same Greek origin "makros" meaning "long , large " within each of these

Macro skills exist a set of Micro skills ; more specific functions that a user of the language might employ. Examples of these macro and micro skills like speaking to public situation 
for the ability of speaking skill, analyzing reading for the reading skill, writing for academic purposes for the writing skill and listening actively for understanding for the listening skill (Richards and Schmidt, $\Upsilon_{\bullet} \cdot$ • $\cdot$ ).

Mozayan $(r+10)$ declares that the concepts of micro-skills and macro-skills are usually used for developing materials and teaching a language, the former are referred to as a set of subs-kills ( enabling skills) or part skills (delineating skills) due to the sentence level while the latter designating skills at the discourse level integrating listening, speaking, reading and writing. Brown ( $r \cdots \vee)$ mentions that Richards has given a set of classification of aural skills, called micro-skills, later it is used by Brown and explained under the terms of micro-skills and macro-skills; the former confines to the sentence level while the latter exceeds this to includes discourse level.

Regarding writing, the macro and micro skills of writing are also known as the subconstructs of writing (ibid). They constitute the emphasis of writing rubrics which are used in standardized and classroom based assessment.

\section{Importance of the Knowledge of Micro and Macro Skills}

The importance of micro and macro skills lies in the roles they play in language teaching and testing since having knowledge of these skills is necessary for the language teachers, due to different purposes required in pedagogy such as ; developing materials, writing objectives, lesson planning, language testing, allocating time, training courses, etc. Brown $(Y \cdots V)$ asserts that the integration of micro and macro skills is essential to determine in details the requirements and things learners need to learn and perform by the language . According to him, "when you plan a specific technique or a strategy, knowledge of micro and macro skills will help you figure out the conceptualized objectives - Another examples such as in evaluation of listening, these micro- and macro skills will help as testing criteria" . Regarding Richards's and Schmidt's words $\left(Y \cdot r_{;}, r_{\cdot}\right) \cdot$ ), the micro-skills are understood as a set of sub-skills or as enabling skills or part skills (in language teaching), these terms are sometimes used to refer to the individual processes and abilities which are put in to practice in carrying out a complex activity.

Accordingly, one may wonder which is more important of these skills ; the micro or the macro. The answer to the questions is declared by Robinson $\left(Y \ldots\right.$, ,p. $\left.{ }^{\top}\right)$ ) and Van Geert and Steenbeek $(Y \cdots 0$, p..$\cup \varepsilon)$ who assert that "it depends on many factors by which macro versus

micro skills, and/ or sub-elements within each macro and micro level that interact and affect each other, depending on the goals and priorities of English second language learners at a certain period of time" . These dimensions are mutually supportive in a way that an improvement in one subset may lead to an improvement in another subset. For example, this close relation and the interaction of the two sub-skills can be seen clearly in the close and positive relationship between lexical and syntactic development in second language acquisition. When the second language learners develop their vocabulary, grammatical structures are shown to become more complex (Robinson \& Mervis, 1991). There is also competition among the dimensions, subsystems, or elements, i.e., macro versus micro skills. This competitive relationship takes place because of the human six brain cannot perform more than one task at a time, i.e., multi-tasking (Van Geert, r..r). For instance, when ESL learners focus their attention on the micro-elements of their writing, involving grammatical accuracy and lexical sophistication, they may ignore issues on the macro-level concerning the coherence and cohesion of their writing. 
Here are examples mentioned by Brown $\left(r_{\ldots \varepsilon}\right)$ for the purpose of syllabus design, the four macro skills of reading, writing, speaking, and listening may be further analyzed into different micro-skills. He then states that oral production, for example, requires the following micro skills:

1. "differentiate between English phonemes and allophones" ,

r. "produce different chunks ",

r. "Producing English stress patterns, rhythms, and intonation patterns ",

乏. "making short forms of speech ",

๑. "Using an adequate number of lexical units to accomplish pragmatic purposes ",

ヶ. " producing fluent speech ",

$\checkmark . "$ Monitoring one's own oral production and using various strategies to enhance the clarity of speech ",

^. "Using elliptical forms ",

१. "Producing utterances in naturally patterned forms ",

1. "Paraphrasing and restating ", and

1)."Using cohesions devices in spoken discourse".

Scrivener( $(\cdot \cdot 1)$ ) and Nation and Macalister $(r \cdot 1 \cdot)$ ) also assert that reading courses, for example, may also focus on sub-skills such as reading carefully for ; finding the gist , scanning reading for details , taking notes, skimming, fast reading, and reading for drawing inferences and information transfer .

Brown $(r \cdots \vee)$ sums up the micro-skills of writing as one of the major skill as follows: Producing correct-spelt words, phrases and sentences including correct graphemes and orthographic patterns .Producing writing at an efficient speed . Producing acceptable number of words and order patterns. Using appropriate grammatical rules ,punctuation, pluralization and capitalization . Paraphrasing ability and correct usage of cohesive and cohesion devices .

\section{Section Three : Procedures}

\section{Methodology}

The aim of the present study is to find out Iraqi EFL teachers' awareness and use of micro and macro language skills .To this end, multiple perspectives are taken into consideration by setting questionnaire and interviewing groups of teachers . The following sections provide a detailed description of the process of selecting samples and data collection

\section{Participants}

Sixty (male and female) teachers and supervisors are selected from the Directory of Education in Wassit province . Purposive sampling (Ary, Jacobs, \& Razavieh, 199•) is used to select the participants with a set of pre-defined characteristics ; that is , the teachers should have had at least $\triangle$ years of teaching experience. The participants are either known to one of the researchers or selected by the directory of education by consulting senior or professional teachers in the field. All the respondents are approached by the researchers (the interviewer) who explained the nature of the study for them . They are assured of the confidentiality of the information they would provide and their free will to participate in the study. The participants' age ranged from $r \cdot$ to $\Sigma \cdot$ with an average of $1 \cdot, 0$ years of teaching experience. 
The participants had all been teaching at different proficiency levels and had the experience of attending teacher training courses (as both pre-service and in-service teachers) in either public or private teacher education centers.

\section{Instrument and Data Collections}

Following the established practice in research related to pedagogical knowledge, a mixed of qualitative and quantitative mode of inquiry is used for data collection (BenPeretz, $r .11)$. More precisely, since the primary aim of the study is to investigate teachers' awareness and use of micro and macro skills, we adopted grounded theory, a research approach in which the theory emerges from the data (Creswell, Hanson, Plano, \& Morales, $r . \vee v)$. Data is collected through separate interviews, which is the most commonly used technique in grounded theory (Petty, Thomson, \& Stew, $r \cdot Y r$ ). This technique is especially useful in applied linguistics when the aim is investigating participants' beliefs and orientations (Mann, $r \cdot 11$ ).

The qualitative mode of the study is done by an interview questions had an openended (questionnaire ) nature and aimed at drawing the participants' ideas about the micro and macro skills as pedagogical knowledge of English teacher to find out their use of these skills. The guideline is then piloted by interviewing an English teacher and a teacher educator, leading to the modification of some of the questions as well as the addition of a number of new ones (see appendix I). In order to come up with comparable data, the same guideline is used for interviewing all the three groups of stakeholders. After finalizing the interview guideline, the participants attended separate semi-structured interviews which were conducted by the researcher. The interviewees worked in various institutions; therefore, the interviewer set an appointment with the individual participants in order to meet them in their office or working place. Because all the respondents were advanced English speakers, the interviews were conducted in English. The interviews lasted between $Y$ to $\leqslant \leqslant$ minutes (an average of $r r, 7 \uparrow$ minutes). They were audio-recorded and transcribed verbatim.

The other mode of inquiry is done by a closed-end questionnaire in which the participants are required to tick ( 1 ) for the item they think as micro skills and $(r)$ for the items they think as macro skills. This questionnaire is also intended to find out the teachers' awareness of micro and macro skills. A pilot study is also done on a sample of teachers to secure reliability, validity and discriminating power of each items. Moreover, the face validity of the questionnaire is secured by exposing it to a jury members of specialists in ELT from different colleges. They prove their validity and suitability . Construct validity is also secured by applying Chi sequre and Allph cronbach formula .

\section{Section Four : Results of the Study}

\section{Results Related to the First Aim}

The first aim of the study is to find out Iraqi EFL teachers' Awareness of micro and macro skills. To achieve this aim one instrument (a questionnaire) is administered on the sample of the study .

The data collected is statistically manipulated to calculate and to find out the arithmetic mean and the standard deviation. To find out the significance of the difference between the arithmetic mean and the theoretical one in each scale, t-test for one independent sample is used. 


\section{Teachers' Awareness of Micro and macro skills}

As illustrated in table ( 1 ), the arithmetic mean of participants' scores in the scale (questionnaire) is $r q, 0$ with a standard deviation $0, r r$ while the theoretical mean is $r r$. The computed t-test value is $r, .0 \leqslant$ which is higher than the critical one which is $r$.

Table (1) T-test Value of the Significance of Difference Between the Arithmetic and Theoretical Means of the Participants' Scores in the Awareness Scale

\begin{tabular}{|c|c|c|c|c|c|c|c|c|}
\hline \multirow[t]{2}{*}{ Variable } & \multirow[t]{2}{*}{$\mathbf{N}$} & \multirow{2}{*}{$\begin{array}{l}\text { Arithmetic } \\
\text { Mean }\end{array}$} & \multirow[t]{2}{*}{ s.d } & \multirow{2}{*}{$\begin{array}{l}\text { Theoretical } \\
\text { Mean }\end{array}$} & \multicolumn{2}{|c|}{ T-test Value } & \multirow{2}{*}{$\begin{array}{l}\text { Level of } \\
\text { Significance }\end{array}$} & \multirow[t]{2}{*}{ d.f } \\
\hline & & & & & Computed & Critical & & \\
\hline $\begin{array}{l}\text { Awareness } \\
\text { of Micro } \\
\text { and macro } \\
\text { skills }\end{array}$ & 7. & $r q, 0$ & 0,77 & $r r$ & $r, .0 \leqslant$ & r & $\begin{array}{l}\text { In favor of } \\
\text { the } \\
\text { theoretical } \\
\text { mean }\end{array}$ & 09 \\
\hline
\end{tabular}

By applying the t-test value for one independent sample we notice that the computed $\mathrm{t}$-value is higher than the tabulated (critical )value and this in turn mean that the results are in favor of the theoretical mean .This also reveals that there is a statistically significant difference between the two mean scores .Therefore , Iraqi ELT teachers' are unaware of these micro and macro skills of listening, speaking, reading and writing .

\section{Results Related to the second Aim}

The second aim of the study is to find out Iraqi EFL teachers' use of micro and macro skills . To achieve this aim an interview is administered on the sample of the study. The data collected is statistically manipulated to calculate and find out the arithmetic mean and the standard deviation. To find out the significance of the difference between

the arithmetic mean and the theoretical one in each scale, t-test for one independent sample is used.

\section{Iraqi EFL Teachers' use of Micro and macro skills}

As illustrated in table $(r)$, the arithmetic mean of participants' scores in the scale(interview) is $I r, r_{0}$ with a standard deviation $\varepsilon, r r$ while the theoretical mean is 10 . The computed t-test value is $\varepsilon, q r$ which is higher than the critical one which is $r$.

Table ( $r$ ) T-test Value of the Significance of Difference Between the Arithmetic and Theoretical Means of the Participants' Scores in the Interview (use ) Scale

\begin{tabular}{|c|c|c|c|c|c|c|c|c|}
\hline \multirow[t]{2}{*}{ Variable } & \multirow[t]{2}{*}{$\mathbf{N}$} & \multirow{2}{*}{$\begin{array}{l}\text { Arithmetic } \\
\text { Mean }\end{array}$} & \multirow[t]{2}{*}{ s.d } & \multirow{2}{*}{$\begin{array}{l}\text { Theoretical } \\
\text { Mean }\end{array}$} & \multicolumn{2}{|c|}{ T-test Value } & \multirow{2}{*}{$\begin{array}{l}\text { Level of } \\
\text { Significance }\end{array}$} & \multirow[t]{2}{*}{ d.f } \\
\hline & & & & & Computed & Critical & & \\
\hline $\begin{array}{l}\text { Use of Micro } \\
\text { and macro } \\
\text { skills }\end{array}$ & 7. & $1 r, r_{0}$ & $\varepsilon, r Y$ & 10 & $\varepsilon, 94$ & $r$ & $\begin{array}{l}\text { In favor of } \\
\text { the } \\
\text { theoretical } \\
\text { mean }\end{array}$ & 09 \\
\hline
\end{tabular}

By applying the t-test value for one independent sample we notice that the computed $\mathrm{t}$-value is higher than the tabulated (critical) and in favor of the theoretical mean .This reveals that the sample is week in this test. This also shows a significant difference between the two means in this scale in favor of the theoretical mean .Therefore, Iraqi EFL teachers almost don't use the micro and macro skills in their teaching .

\section{Conclusions}

According to the results of the study, it is concluded that : 
1. Iraqi EFL teachers are unaware of the micro and macro skills in the their teaching ; that is, they teach the four language skills without having, if any, ideas about the fact that language has sub-skills which are ; micro and macro skills necessary in carrying out any English language lesson .

$r$. Iraqi EFL teachers do not use micro and macro skills in the teaching processes including ; teaching any lessons and activities , setting objectives , planning a lesson or setting tests because they ignore these sub-skills and they know only the four major skills with no idea about the micro and macro skills .

\section{Recommendations}

According to the conclusions of the study, it is recommended that :

1. Raise the Iraqi EFL teachers' awareness of the micro and macro skills by interviewing them or giving them training courses in this regard.

$r$. Give a due account in the Teachers' book ; presenting the teachers with the main language skills and the micro and macro skills that go under these main skills and how these skills are interrelated to each other .

$r$. Highlighting the importance of the knowledge of the micro and macro skills and their essentials roles they play in language teaching and testing since no single lesson or activity can be carried out without having knowledge of these skills.

\section{References}

Alderson ,C. $(\uparrow \cdots)$. Assessing reading. Cambridge : Cambridge University Press.

Ary, D., Jacobs, C., \& Razavieh, A. (199•). Introduction to research in education. Fort Worth, TX: Holt, Rinehart and Winston, Inc.

Australian Journal of Teacher Education $r \cdot 1 r$ Impact of Awareness Raising about Listening Micro-skills on the Listening Comprehension Enhancement: An Exploration of the Listening Micro-skills in EFL Classes Amir Rezaei University of Malaya, a_rezaie@ siswa.um.edu.my

Basturkmen, H. $\left(\begin{array}{r}\top \\ \top\end{array}\right)$. Ideas and options in English for specific purposes. New Jersey: Lawrence Erlbaum.

Ben-Peretz, M. $(r \cdot \mid 1)$. Teacher knowledge: What is it? How do we uncover it? What are its implications for schooling? Teaching and Teacher Education, $r \vee, r-q$.

Brown, H. D. ( 9 • $)$. Principles of language learning and teaching. Englewood Cliffs, N.J: Prentice-Hall.

Brown, H. D. $(Y \cdots)$ ). Teaching by principles: An interactive approach to language pedagogy. White Plains, NY: Addison-Wesley.

Brown, H. D. $(\uparrow \cdots \varepsilon)$. Language assessment: Principles and classroom practices. NY: Longman.

Brown, H. D. $(Y \cdots \vee)$. Teaching by principles: An introductive approach to language pedagogy ( $r$ rd ed.). NY: Pearson Education.

Brown, J. D. ( $199 \wedge)$. Does IELTS preparation work? An application of the context-adaptive model of language program evaluation. IELTS Research Reports .

Cambridge, E. $(\uparrow \cdot \mid l)$. Using the CEFR: Principles of good practice. Cambridge ESOL. 
Craven, E. $(r \cdot \mid r)$. The quest for IELTS Band $v, \cdot$ : Investigating English language proficiency development of international students at an Australian university. IELTS Research Reports .

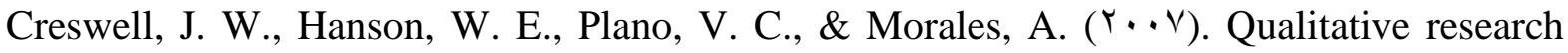
designs: Selection and implementation. The Counseling Psychologist, ro, r rצ_r

ELT Voices- International Journal for Teachers of English Volume ( $\left.{ }^{0}\right)$, Issue ( $(7),{ }^{-}-Y(Y \cdot 10)$ ISSN Number: Yrr.-q1 צ (http://www.eltvoices.in)

Ellis, R. $\left(Y \cdot Y^{\cdot}\right)$. Second language acquisition research and language-teaching materials. In N. Harwood (Ed.), English language teaching materials: Theory and practice (pp. $\leqslant \varepsilon_{-} \wedge$ ). Cambridge: Cambridge University Press.

Evans, N. W., James Hartshorn, K., \& Anderson, N. J. (Y. $\cdot \bullet)$. A principled approach to content-based materials development for reading. In N. Harwood (Ed.), English language teaching materials: Theory and practice. Cambridge: Cambridge University Press.

Farhady, H. $(\uparrow \cdots 0)$. Reflection on and directions for ESP material development in SAMT. In G. Kiany \& M. Khayamdar (Eds.), Proceedings of the first national ESP/EAP conference. Tehran: SAMT.

Harwood, N. ( $r \cdot \cdot)$. Issues in material development and design. In N. Harwood (Ed.), English language teaching materials: Theory and practice. Cambridge: Cambridge University Press.

Kumaravadivelu,B. $(r \cdots r)$. Beyond methods: Macrostrategies for language teaching. New Haven, CT: Yale University Press.

Kumaravadivelu, B. $(\uparrow \cdots\urcorner)$. Understanding language teaching: From method to postmethod. Mahwah, NJ: Lawrence Erlbaum Associates.

Mann, S. $(r \cdot 11)$. A critical review of qualitative interviews in applied linguistics. Applied Linguistics, $r$ T ( ) $), T_{-} r \varepsilon$.

McDonough, D., \& Shaw, C. $(r \cdots r)$. Materials and methods in ELT: A teacher's guide ( $r$ nd ed.). Malden: Blackwell Publishing.

McDonough, D., Shaw, C., \& Masuhara, H. $(r \cdot 1 r)$. Materials and methods in ELT: A teacher's Guide ( ${ }^{r}$ rd ed.). Malden Blackwell Publishing.

Morrison, G. R., Ross, S. M., \& Kemp, J. E., $(\uparrow \cdots 1)$. Designing effective instruction ( ${ }^{\top}$ rd ed.). New York: John Wiley.

Munby, J. ( $9 \vee \wedge)$. Communicative syllabus design. Cambridge: Cambridge University Press.

Myles, J. $(r \ldots r)$. Second language writing and research: The writing process and error analysis in student texts. . Retrieved from http://www.jbm $r @$ post.queensu.ca.

Nation, I. S. P., \& Macalister, J. (†• • • ). Language curriculum design. New York: Routledge.

Nunan, D. ( 9 १९). Syllabus design. Oxford: Oxford University Press.

Petty, N. J., Thomson, O. P., \& Stew, G. $(r \cdot I r)$. Ready for a paradigm shift? Part $r$ : Introducing qualitative research methodologies and methods. Manual Therapy, IV, rV^- $r \wedge \varepsilon$.

Richards, J. C. $\left(Y_{\cdots}\right)$ ). Curriculum development in language teaching. Cambridge: Cambridge University Press. 
Richards, J. C. (199•). The language teaching matrix. New York: Cambridge University Press.

Richards, J. C. $\left(\Upsilon^{\prime} \cdot\right)$. Curriculum development in language teaching. Cambridge: Cambridge University Press.

Richards, J. C. $(r \cdot \mid r)$. Curriculum approaches in language teaching: Forward, central, and backward design. RELC Journal, $\leqslant \varepsilon(1), 0-r r$.

Richards, J. C., \& Schmidt, R. (Ed.). ( $(\cdots$. $)$. Longman dictionary of applied language teaching and applied linguistics. London: Pearson Education Limited. ELT Voices-Volume $(0)$, Issue $(\top),(r+10)$

Richards, J. C., \& Schmidt, R. (Y.1•). Longman dictionary of language Teaching and applied linguistics ( $\Sigma$ th ed.). Longman: Pearson Education.

Richards, J. C. $\left(\Upsilon_{\cdots}\right)$ ). Curriculum development in language teaching. Cambridge: Cambridge University Press. $[r \cdot]$

Richards, J. C. (199•). The language teaching matrix. New York: Cambridge University Press. [ $\left.{ }^{\prime}\right]$ ] Richards, J. C. $(r \ldots l)$. Curriculum development in language teaching. Cambridge: Cambridge University Press. $[Y Y]$

Richards, J. C. $(Y \cdot \mid r)$. Curriculum approaches in language teaching: Forward, central, and

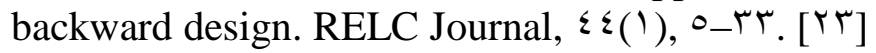

Richards, J. C., \& Schmidt, R. (Ed.). ( $(\cdots r)$. Longman dictionary of applied language teaching and applied linguistics. London: Pearson Education Limited. ELT Voices-Volume $(0)$, Issue $(\top),(r \cdot 10) \mathrm{V}$

Richards, J. C., \& Schmidt, R. $\left(r^{\prime} \cdot \bullet\right)$. Longman dictionary of language Teaching and applied linguistics ( $\Sigma$ th ed.). Longman: Pearson Education.

Materials to Develop Microskills and Macroskills: Are There Any Principles? Mohammad Reza Mozayan Ph.D. candidate in TEFL, English Language Department, Shahid SadoughiUniversity of Medical Sciences and Health Services, Yazd, Iran. Corresponding email address mozayan「^@yahoo.com

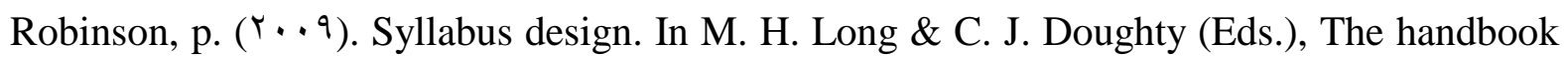

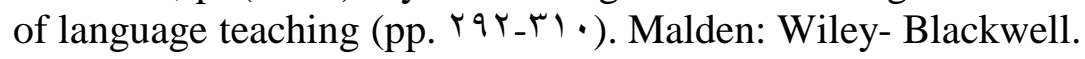

Scrivener, J. $(r \cdot \mid l)$. Learning teaching: The essential guide to English language education ( $r$ rd ed.). Oxford: Macmillan Education.

Tomlinson, B. $(\uparrow \cdot 1 \cdot)$. Principles of effective materials development. In N. Harwood (Ed.), English language teaching materials: Theory and practice Cambridge: Cambridge University Press.

Tomlinson, B. $(Y \cdot 11)$. Introduction: Principles and procedures of materials development. In B. Tomlinson (Ed.), Materials development in language teaching ( ${ }^{\mathrm{n}} \mathrm{nd}$ ed.). Cambridge: Cambridge University Press.

Tomlinson, B. $(Y \cdot \mid r)$. Materials development for language learning and teaching. State-of-

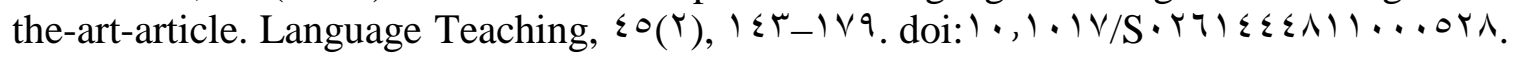

Ur, P. $(r \cdot \mid r)$. A course in English language teaching ( $r$ nd ed.). Cambridge: Cambridge University Press. [r/] White, R. V. ( $\mid 9 \wedge \wedge)$. The ELT curriculum: Design, innovation and management. Oxford: Basil Blackwell.

Nunan, D. (19^9). Syllabus design. Oxford: Oxford University Press. [19] 
Appendix (1)

The interview guideline

Introduction

The purpose of our study is to investigate Iraqi EFL teachers' Awareness and Use of micro and macro skills .To probe into this matter, The researcher has decided to interview English language teachers to know your ideas in this regard. If you do not have any question, we can start with the interview.

Warm up:

1.Would you please introduce yourself ?

- Name and age

- Degree and major

- kind of teaching experience you have

- Past/present school/institution (private sector/public sector/both)

- Age and level of students (for teachers and language teacher supervisors ) - How many hours per week?

r. What made you become a teacher? Why do you choose teaching?

r.What do you like more about teaching? «.When you hear the word "teaching", what words or images come to your mind?

\section{Main questions:}

1. How many skills are there in the English language ? ( $\Sigma)$

$r$. what are the productive skills and the receptive skills ? $(r)$

$r$. what are the most important skills? why? $(r)$

\&. Have you ever heard about the micro and macro skills ?(1)

๑. what is meant by the micro skills ?(1)

7. what is meant by the macro skills ?(1)

$\checkmark$. Do you think they are necessary ? (1)

$\wedge$. What are the other names of micro and macro skills ? $(r)$

9. Do you use and adopt the classification of micro and macro skills in your work as a teacher ?(1)

1 . When and where do you use them? $(r)$

11 . Give some examples of the micro and macro listening skills?( $\left.{ }^{r}\right)$

$1 Y$. Give some examples of the micro and macro speaking skills? $\left.{ }^{(}\right)$

$1 r$. Give some of the micro and macro reading skills? $(r)$

1 . Give some of the micro and macro writing skills?( $(r)$

10. Can you manage your teaching without them ?(1)

Appendix $(r)$

The questionnaire guideline

Read the following items found in the following tables there of ; listening, speaking ,reading and writing, then Tick ( 1 ) for the items you think Micro-skills and $(r)$ for the Macro-skills ones:

Listening

\begin{tabular}{|l|l|l|l|}
\hline No & Item(s) & 1 & $r$ \\
\hline
\end{tabular}

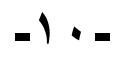




\begin{tabular}{|c|c|}
\hline 1 & $\begin{array}{l}\text { "Discriminate among the distinctive sounds of English or Listening to } \\
\text { discriminate between distinctive sounds" }\end{array}$ \\
\hline r & "Retain chunks of language of different lengths in short-term memory" \\
\hline$r$ & $\begin{array}{l}\text { "Recognize English stress patterns, words In stressed and unstressed } \\
\text { positions, rhythmic structure, intonation contours, and their role in signaling } \\
\text { information" }\end{array}$ \\
\hline$\varepsilon$ & "Recognize reduced forms of words" \\
\hline 0 & $\begin{array}{l}\text { "Distinguish word boundaries, recognize a core of words, and interpret word } \\
\text { order patterns and their significance" }\end{array}$ \\
\hline 7 & "Process speech at different rates of delivery" \\
\hline $\mathrm{V}$ & $\begin{array}{l}\text { "Process speech containing pauses, errors, corrections, and other } \\
\text { performance variables" }\end{array}$ \\
\hline$\Lambda$ & $\begin{array}{l}\text { "Recognize grammatical word classes (nouns, verbs, etc.), systems (e.g., } \\
\text { tense, agreement, pluralization), patterns, rules, and elliptical forms" }\end{array}$ \\
\hline 9 & $\begin{array}{l}\text { "Detect sentence constituents and distinguish between major and minor } \\
\text { constituents" }\end{array}$ \\
\hline 1. & $\begin{array}{l}\text { "Recognize that a particular meaning may be expressed in different } \\
\text { grammatical forms" }\end{array}$ \\
\hline 11 & "Recognize cohesive devices in spoken discourse" \\
\hline Ir & $\begin{array}{l}\text { "Recognize the communicative functions of utterances, according to } \\
\text { situations, participants, goals" }\end{array}$ \\
\hline ir & "Infer situations, participants, goals using real-world knowledge" \\
\hline $1 \leq$ & $\begin{array}{l}\text { "From events and ideas described, predict outcomes, infer links and } \\
\text { connections between events, deduce causes and effects, and detect such } \\
\text { information, generalization, and exemplification" }\end{array}$ \\
\hline 10 & "Distinguish between literal and implied meanings " \\
\hline 17 & $\begin{array}{l}\text { "Use facial, kinesic, body language, and other nonverbal clues to decipher } \\
\text { meanings" }\end{array}$ \\
\hline IV & $\begin{array}{l}\text { "Develop and use a battery of listening strategies, such as detecting key } \\
\text { words, guessing the meaning of words from context, appealing for help, and } \\
\text { signaling comprehension thereof" }\end{array}$ \\
\hline 11 & "Ability to guess the meanings of unfamiliar words from the context" \\
\hline 19 & "Listening for gist or general idea" \\
\hline r. & "Listening for specific information and important details" \\
\hline Y & "Listening for key words" \\
\hline Yr & "Recognizing the topic" \\
\hline$r r$ & "Making inferences and understanding the speaker's purpose" \\
\hline
\end{tabular}

Speaking

\begin{tabular}{|l|l|l|l|}
\hline No & Item(s) & r & \\
\hline 1 & "Produce differences among English phonemes and allophones" & \\
\hline$r$ & "Produce chunks of language of different lengths" & \\
\hline$r$ & $\begin{array}{l}\text { "Produce English stress patterns, words in stressed and unstressed positions, } \\
\text { rhythmic structure, and intonation contours" }\end{array}$ & \\
\hline$\varepsilon$ & "Produce reduced forms of words and phrases" & \\
\hline
\end{tabular}




\begin{tabular}{|c|c|}
\hline - & $\begin{array}{l}\text { "Use an adequate number of lexical units (words) to accomplish pragmatic } \\
\text { purposes" }\end{array}$ \\
\hline 7 & "Produce fluent speech at different rates of delivery" \\
\hline $\mathrm{V}$ & $\begin{array}{l}\text { "Monitor one's own oral production and use various strategic devices - pauses, } \\
\text { fillers, self-corrections, backtracking - to enhance the clarity of the message" }\end{array}$ \\
\hline$\Lambda$ & $\begin{array}{l}\text { "Use grammatical word classes (nouns, verbs, etc.), systems (e.g., tense, } \\
\text { agreement, pluralization), word order, patterns, rules, and elliptical forms" }\end{array}$ \\
\hline 9 & $\begin{array}{l}\text { "Produce speech in natural constituents: in appropriate phrases, pause groups, } \\
\text { and sentence constituents" }\end{array}$ \\
\hline $1 \cdot$ & "Express a particular meaning in different grammatical forms" \\
\hline 11 & "Use cohesive devices in spoken discourse" \\
\hline ir & $\begin{array}{l}\text { "Appropriately accomplish communicative functions according to situations, } \\
\text { participants, and goals" }\end{array}$ \\
\hline ir & $\begin{array}{l}\text { "Use appropriate styles, registers, implicature, redundancies, pragmatic } \\
\text { conventions, conversation rules, floor-keeping and-yielding, interrupting, and } \\
\text { other sociolinguistic features in face-to-face conversations" }\end{array}$ \\
\hline $1 \varepsilon$ & $\begin{array}{l}\text { "Convey links and connections between event and communicate such relations as } \\
\text { focal and peripheral ideas, events and feelings, new information and given } \\
\text { information, generalization and exemplification" }\end{array}$ \\
\hline 10 & $\begin{array}{l}\text { "Convey facial features, kinesics, body language, and other nonverbal cues along } \\
\text { with verbal language" }\end{array}$ \\
\hline 17 & $\begin{array}{l}\text { "Develop and use a battery of speaking strategies, such as emphasizing key words, } \\
\text { rephrasing, providing a context for interpreting the meaning of words, appealing } \\
\text { for help, and accurately assessing how well your interlocutor is understanding } \\
\text { you" }\end{array}$ \\
\hline
\end{tabular}

\section{Reading}

\begin{tabular}{|c|c|c|c|}
\hline No & $\operatorname{Item}(\mathbf{s})$ & 1 & r \\
\hline 1 & $\begin{array}{l}\text { "Discriminate among the distinctive graphemes (letters or letter combinations that } \\
\text { produce a phoneme) and orthographic patterns of English" }\end{array}$ & & \\
\hline$r$ & "Retain chunks of language of different lengths in short-term memory" & & \\
\hline$r$ & "Process writing at an efficient rate of speed to suit the purpose" & & \\
\hline$\varepsilon$ & $\begin{array}{l}\text { "Recognize a core of words and interpret word order patterns and their } \\
\text { significance" }\end{array}$ & & \\
\hline 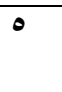 & $\begin{array}{l}\text { "Recognize grammatical word classes (nouns, verbs, etc.), systems (e.g., tense, } \\
\text { agreement, pluralization), patterns, rules, and elliptical forms" }\end{array}$ & & \\
\hline 7 & $\begin{array}{l}\text { "Recognize that a particular meaning may be expressed in different grammatical } \\
\text { forms" }\end{array}$ & & \\
\hline $\mathrm{V}$ & $\begin{array}{l}\text { "Recognize cohesive devices in written discourse and their role in signaling the } \\
\text { relationship between and among clauses" }\end{array}$ & & \\
\hline$\Lambda$ & $\begin{array}{l}\text { "Recognize the rhetorical conventions of written discourse and their significance for } \\
\text { interpretation" }\end{array}$ & & \\
\hline 9 & $\begin{array}{l}\text { "Recognize the communicative functions of written texts, according to form and } \\
\text { purpose" }\end{array}$ & & \\
\hline 1. & $\begin{array}{l}\text { "Infer context that is not explicit by activating schemata (using background } \\
\text { knowledge)" }\end{array}$ & & \\
\hline 11 & $\begin{array}{l}\text { "From described events, ideas, etc., infer links and connections between events, } \\
\text { deduce causes and effects, and detect such relations as main idea, supporting idea, } \\
\text { new information, given information, generalization, and exemplification" }\end{array}$ & & \\
\hline ir & "Distinguish between literal and implied meanings" & & \\
\hline
\end{tabular}




\begin{tabular}{|l|l|l|}
\hline $1 \Gamma$ & $\begin{array}{l}\text { "Detect culturally specific references and interpret them in a context of appropriate } \\
\text { cultural schemata" }\end{array}$ & \\
\hline I & $\begin{array}{l}\text { "Develop and use a battery of reading strategies, such as scanning and skimming, } \\
\text { detecting discourse markers, guessing the meaning of words from context, and } \\
\text { activating schemata for the interpretation of texts" }\end{array}$ & \\
\hline
\end{tabular}

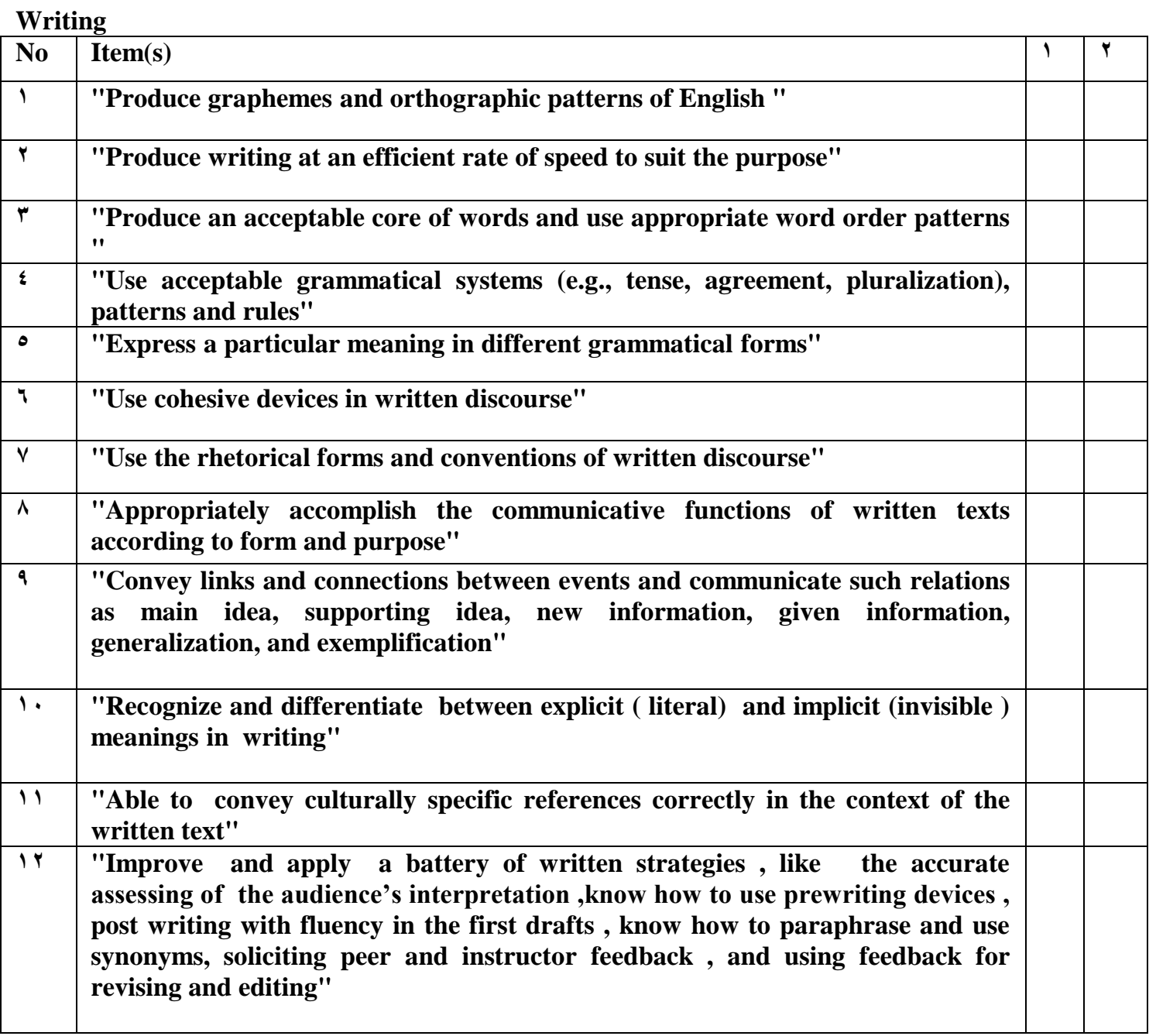

